\title{
Integrated Effects of Root-Zone Temperatures and Phosphorus Levels on Aeroponically-Grown Lettuce (Lactuca sativa L.) in the Tropics
}

\author{
H.Y. Luo, S.K. Lee and J. He* \\ Natural Sciences and Science Education Academic Group, National Institute of Education, Nanyang Technological \\ University, 1 Nanyang Walk, Singapore 637616
}

\begin{abstract}
In this study, butterhead lettuce (Lactuca sativa L. cv. Baby Butter) plants were grown at three root-zone temperatures (RZTs): $25^{\circ} \mathrm{C}, 30^{\circ} \mathrm{C}$ and ambient-RZT (A-RZT) ranging from $26^{\circ} \mathrm{C}-42^{\circ} \mathrm{C}$ while their shoots were maintained at hot ambient temperature ranging from $26^{\circ} \mathrm{C}-42^{\circ} \mathrm{C}$. Three phosphorus $(\mathrm{P})$ concentrations: $-25 \% \mathrm{P}$ (minus $\mathrm{P}, 23.25 \mathrm{ppm}$ ), control (31.00ppm) and $+25 \%$ P (plus P, 38.75ppm) were supplied to the plants at each RZT using Netherlands Standard Nutrient Solution. Interactions between RZT and $\mathrm{P}$ concentrations on productivity, root morphology, maximum photosynthetic $\mathrm{O}_{2}$ evolution $\left(\mathrm{P}_{\max }\right), \mathrm{P}$ uptake and its partitioning between shoot and root were studied. Lettuce plants grown with the plus $\mathrm{P}$ concentration at $25^{\circ} \mathrm{C}-\mathrm{RZT}$ had the highest productivity, highest $\mathrm{P}_{\max }$, highest shoot and root $\mathrm{P}$ concentrations. However, all the root morphological parameters studied were the greatest in plants grown with the minus $\mathrm{P}$ at $25^{\circ} \mathrm{C}-\mathrm{RZT}$. Higher $\mathrm{P}$ concentration in the solution and $25^{\circ} \mathrm{C}-\mathrm{RZT}$ resulted in higher portion of the absorbed $\mathrm{P}$ partitioned to the shoots. Integrated effects of RZT and P concentration on the productivity, root morphology, photosynthesis and P uptake were discussed.
\end{abstract}

Key Words: Chlorophyll fluorescence $\mathrm{F}_{\mathrm{v}} / \mathrm{F}_{\mathrm{m}}$ ratio, photosynthesis, phosphorus, plant growth, root morphology, root-zone temperature.

\section{INTRODUCTION}

Temperate and subtropical crops, such as lettuce (L. sativa) and capsicum (Capsicum annuum), have been successfully grown in the tropics by exposing their roots to certain cool temperatures $\left(15\right.$ to $\left.25^{\circ} \mathrm{C}\right)$ while their shoots were maintained at hot ambient temperature [1-4]. Under such conditions, it was observed that $\mathrm{P}$ concentration in nutrient solution had strong effect on their growth and productivity.

The effects of availability of $\mathrm{P}$ on the growth and productivity of plants had been well studied. In the study with bean (Phaseolus vulgaris) plant, Mikulska et al. (1998) [5] found that after 18 days of $\mathrm{P}$ starvation, the accumulations of fresh weight (FW), dry weight (DW) and leaf area were only 45 to $55 \%$ and $60 \%$, respectively, compared to control plants supplied with sufficient P. With lettuce plants, Xu et al. (2004) [6] revealed that increasing solution-P concentration from 0.2 to $1.0 \mathrm{mM}$ significantly increased the canopy $\mathrm{FW}$ by 12 $25 \%$. Some specific growth factors related to $P$ have been identified. For example, $\mathrm{P}$ increases stem strength, improves flower formation and seed production, improves crop quality; and increases resistance to diseases [5, 7, 8]. Results of Lynch et al. (1991) [9] suggested that decrease in leaf number and size was one of the earliest and most reliable responses of bean plants to $\mathrm{P}$ deficiency. In lettuce plants, Soundy et al. (2001) [10] found that both shoot FW and DW

\footnotetext{
*Address correspondence to this author at the Natural Sciences and Science Education Academic Group, National Institute of Education, Nanyang Technological University, 1 Nanyang Walk, Singapore 637 616; Tel: 6567903817; Fax: 65-68969432; E-mail: jie.he@ nie.edu.sg
}

as well as leaf area increased quadratically in response to increased $\mathrm{P}$ concentrations from 0 to $45 \mathrm{mg} / \mathrm{L}$.

In a study of $L$. sativa cv. Palma under aeroponical conditions, Tan et al. (2002) [4] found that plants grown at optimum cool RZT had higher leaf P concentration compared to the plants grown at hot A-RZT. With muskmelon ( $\mathrm{Cucu-}$ mis melo L. 'Gold Star'), Stoltzfus et al. (1998) [11] obtained similar results. These results suggested that uptake of P by plants and its accumulation within plants were strongly affected by RZTs.

It has been well documented that RZT affects root growth and development $[4,12,13]$. In lettuce plants, total root length, total root surface area and number of root tips of the plants grown at $20^{\circ} \mathrm{C}$-RZT were much greater compared to the plants grown at A-RZT [4]. On the other hand, roots of P-deficient plants were typically longer and slender [14, 15] and often with abundant root hairs [16], resulting in a large root surface for P capture. However, other results indicated that root growth was unaffected or even stimulated by $\mathrm{P}$ deficiency $[6,14]$. There is little research on the interaction between different $\mathrm{P}$ concentrations in the medium and RZT on lettuce plant growth and development. In this study, $\mathrm{P}$ concentrations in nutrient solution were increased (plus $\mathrm{P}$ ) or decreased (minus P) by $25 \%$ in reference to the $\mathrm{P}$ concentration in Netherlands Standard Nutrient Solution (as a control). The effects of RZT and nutrient $\mathrm{P}$ concentration on plant productivity, root morphology, photosynthesis, $\mathrm{P}$ uptake and transport were determined. The objective was to establish the optimal P concentration for the commercial production of lettuce plant in the tropics. 


\section{MATERIALS AND METHODS}

\section{Cultivation of Experimental Plant}

Butterhead lettuce (Lactuca sativa L. cv. Baby Butter) was chosen as experimental material. It is hereby simply referred to as lettuce. Seeds were obtained from a commercial seed producer in Holland. Three days after germination, the seedlings were transferred onto polyurethane cubes with a cut at the center and socked with water and placed in trays. The trays were transferred to a greenhouse for 15 days for hardening. The seedlings were then transplanted to the aeroponic system as previously described by Lee (1993) [17]. Aeroponics is a modified hydroponic culturing system. Roots of the plants were suspended in the air within an enclosed chamber (through). Nutrient solution was pumped through a series of discharge pipes installed at the base of trough. Lower RZTs were obtained by misting roots with cooled nutrient solution. The maintaining of lower nutrient solution temperature was achieved by a sensor within the trough connected to a microprocessor [17].

Roots were maintained at three temperatures: $25^{\circ} \mathrm{C}, 30^{\circ} \mathrm{C}$ and A-RZT within a sealed trough while the aerial parts were exposed to the fluctuating ambient temperature $\left(26^{\circ} \mathrm{C}-42^{\circ} \mathrm{C}\right)$ under $100 \%$ of prevailing solar radiation with maximum photon flux density (PFD) of $1200 \mu \mathrm{mol} \mathrm{s} \mathrm{s} \mathrm{s}^{-1}$. Modified full strength Netherlands Standard Solution [18] was used as control. The standard nutrient solution had the following composition: Ca, 180.5ppm; N, 166.4ppm; P, 31.0ppm; K, 265.3ppm; Mg, 48.7ppm; Fe, 13.0ppm; Mn, 1.0ppm; B, $0.1 \mathrm{ppm} ; \mathrm{Zn}, 0.01 \mathrm{ppm}$; Cu, 0.01ppm; Mo, 0.3ppm. Some plants were also grown in nutrient solution with increased (plus $\mathrm{P}, 38.75 \mathrm{ppm}$ ) or decreased (minus $\mathrm{P}, 23.25 \mathrm{ppm}$ ) $\mathrm{P}$ concentration by $25 \%$ while the rest of the elements remained the same.

The design of the experiment was shown in Table 1. Each treatment had 60 plants with a growth duration of 35 days. At the end of the experiment, 5 plants, considered as replications, were harvested randomly from the aeroponic trough for analysis of shoot and root FW and DW, root morphology, photosynthesis, and $\mathrm{P}$ concentration.

\section{Measurement of Shoot and Root FW and DW}

35 days after transplanting, the whole lettuce plants were removed from the aeroponic trough and the polyurethane cube was removed carefully from individual root system. Roots and shoots were separated from five plants. Both shoots and roots were dried carefully with blotting paper and weighed separately. After taking the FW, all the tissues were wrapped with aluminum foil and dried at $80^{\circ} \mathrm{C}$ for 4 days to obtain the DW.

\section{Analysis of Root Morphology}

The root morphology was analyzed with WIN MAC RHIZO scanner equipped with the WIN MAC RHIZO V 3.9 program (Regent Instruments INC., Canada) 35 days after transplanting. The roots were detached from their shoots on another five plants and then placed in a tray $(20 \mathrm{~cm} \times 25 \mathrm{~cm})$ with water. The water served to separate out the roots and keep them moist. The parameters of total root length, number of root tips, root surface area and root volume were determined by the program.

\section{Measurement of Maximum Photosynthetic Rate $\left(\mathbf{P}_{\max }\right)$}

After transplanting for $35 \mathrm{~d}$, a $10 \mathrm{~cm}^{2}$ leaf disc was cut from the leaf and placed in a saturated $\mathrm{CO}_{2}$ condition $(1 \%$ $\mathrm{CO}_{2}$ from a $1 \mathrm{~mol} / \mathrm{L}$ carbohydrate/bicarbonate buffer, $\left.\mathrm{pH} 9\right)$ as described by Ball et al. (1987) [19]. $\mathrm{P}_{\max }$ of oxygen evolution was obtained using an oxygen electrode system (Model LD2, Hansatech Ltd, King Lynn, Norfork, England) at $25^{\circ} \mathrm{C}$ under photon flux density (PFD) of $1000 \mu \mathrm{mol} \mathrm{m}^{-2} \mathrm{~s}^{-1}$.

\section{Determination of $\mathbf{P}$ Concentration in the Plant Tissue and Calculation of Total $P$}

The same plants used for the measurement of shoot and root FW and DW were used for this analysis. After measuring shoot and root DW, $0.05 \mathrm{~g}$ of dry sample was placed into a digestion tube with a Kjeldahl tablet and $5 \mathrm{ml}$ of concentrated sulphuric acid. $2.5 \mathrm{ml}$ of digested liquid was transferred into a $100 \mathrm{ml}$ volumetric flask and deionised water was used to top up till $100 \mathrm{ml}$. P concentration in this solution was determined colorimetrically (Murphy and Riley, 1962) [20] using a spectrometer (Beckman DU 650, USA). Total $\mathrm{P}$ content was calculated as: $\mathrm{P} \times \mathrm{DW}$.

\section{Statistical Analysis}

All data obtained in the study were statistically analyzed by ANOVA (Microsoft Excel Windows 2000). The comparisons were made between control $\mathrm{P}$ and $+25 \% \mathrm{P}$ or control $\mathrm{P}$ and $-25 \% \mathrm{P}$ at each RZT by $t$-test. Comparisons were also conducted among the three RZTs supplied with the same level of P. When significant $(P<0.05)$ differences occurred, means were separated by LSD.

\section{RESULTS AND DISCUSSION}

\section{Plant Productivity}

In a vegetable farm, plant productivity is expressed as FW. At each given RZT, shoot FW of lettuce plants grown with the plus $\mathrm{P}$ was significantly higher $(P<0.05)$ than the control P plants. Meanwhile, shoot FW of lettuce plants grown with the minus $\mathrm{P}$ was significantly lower $(P<0.05)$

Table 1. The Outline of Experimental Treatments. Plants were Fed with Three $P$ Concentrations $($ Minus 25\% $P=23.25 p p m$, Control $=31.00 \mathrm{ppm}$, and Plus $25 \% \mathrm{P}=38.75 \mathrm{ppm})$ and Roots were Exposed to Three Different Temperatures $\left(25^{\circ} \mathrm{C}\right.$, $30^{\circ} \mathrm{C}$, and A-RZT Ranging from $26^{\circ} \mathrm{C}$ to $42^{\circ} \mathrm{C}$ ) when Grown Under Each $P$ Treatment

\begin{tabular}{|c|c|c|c|c|c|c|c|c|}
\hline \multicolumn{3}{|c|}{ Minus P } & \multicolumn{3}{|c|}{ Control P } & \multicolumn{3}{|c|}{ Plus P } \\
\hline $25^{\circ} \mathrm{C}-$ & $30^{\circ} \mathrm{C}-$ & A-RZT & $25^{\circ} \mathrm{C}-$ & $30^{\circ} \mathrm{C}-$ & A-RZT & $25^{\circ} \mathrm{C}-$ & $30^{\circ} \mathrm{C}-$ & A-RZT \\
\hline
\end{tabular}


than the control $\mathrm{P}$ plants. At each given $\mathrm{P}$ concentration, shoot FW of lettuce plants grown at A-RZT was significantly lower than that of plants grown at $25^{\circ} \mathrm{C}$-RZT $(P<$ $0.05)$ and $30^{\circ} \mathrm{C}-\mathrm{RZT}(P<0.05)$. Meanwhile, shoot FW of lettuce plants grown at $30^{\circ} \mathrm{C}$-RZT was significantly lower $(P$ $<0.05$ ) than the plants grown at $25^{\circ} \mathrm{C}$-RZT (Fig. 1A). These results suggest that growth of lettuce in the tropics was very sensitive to the change in RZTs, but increased nutrient $\mathrm{P}$ concentration could alleviate the detrimental effect resulted from the higher RZT.

On the contrary, at each given RZT, lettuce plants grown with the minus $\mathrm{P}$ concentration had higher root $\mathrm{FW}(P<$ $0.05)$ while those plants grown with the plus $\mathrm{P}$ concentration had lower $(P<0.05)$ root $\mathrm{FW}$ as compared to the control plants. High A-RZT significantly reduced the root FW, regardless of $\mathrm{P}$ concentration. At each given $\mathrm{P}$ concentration, root $\mathrm{FW}$ of A-RZT plants was significantly lower than that of $30^{\circ} \mathrm{C}(P<0.05)$ and $25^{\circ} \mathrm{C}$-RZT plants $(P<0.05)$. Meanwhile, root $\mathrm{FW}$ of plants grown at $25^{\circ} \mathrm{C}-\mathrm{RZT}$ was significantly higher $(P<0.05)$ than that of $30^{\circ} \mathrm{C}-\mathrm{RZT}$ plants. At $25^{\circ} \mathrm{C}$-RZT, despite of the lowest root $\mathrm{FW}$ was found for the plus $\mathrm{P}$ among the three $\mathrm{P}$ concentrations, root $\mathrm{FW}$ was higher than that of lettuce plants grown at A-RZT with the minus $\mathrm{P}$ concentration (Fig. 1B). These results indicate the override effect of RZT on $\mathrm{P}$ concentration in nutrient solution. The results of He and Lee (2001) [21] demonstrated that lettuce plants grown at $25^{\circ} \mathrm{C}$-RZT had much higher shoot and root FW and DW compared to that of A-RTZ plants. They attributed the effect of hot A-RZT on the reduced shoot and root FW and DW to the water stress and thus resulted in stomatal and non-stomatal limitation of photosynthesis. Similar results were obtained by Qin et al. (2002) [22] and Tan et al. (2002) [4]. Higher productivity of lettuce plants grown with higher $\mathrm{P}$ concentration in the present study could be related to cell expansion, as leaf cell expansion, especially expansion of epidermal cells, was very sensitive to tissue $\mathrm{P}$ concentration [23]. Lee and Cheong (1996) [24] suggested this lower RZT per se could have direct effects on total physiology of the plants that resulting growth and development of plants, as lower RZT affect nutrient uptake by plants [25, 26]. On the other hand, root tissues, especially meristems, are sites of synthesis of important hormones, such as auxins, cytokinins and gibberellins [27-29]. Higher growth of roots for the plants grown at $25^{\circ} \mathrm{C}$-RZT could affect morphogenesis of the shoots.

The shoot/root ratio of FW for plants grown with the plus $\mathrm{P}$ was 2.17-fold higher than that of the control $\mathrm{P}$ plants. The shoot/root ratio of FW for the control P plants was 1.33-folds higher than that of the minus $\mathrm{P}$ plants (Fig. 1C). Similar results were found for $30^{\circ} \mathrm{C}-\mathrm{RZT}$ and A-RZT plants. Changes of shoot and root DW as well as shoot/root ratio of DW in responses to different $\mathrm{P}$ concentrations and RZTs were similar to those of the FWs (data not shown). These results indicate that both RZTs and P concentrations in nutrient solution had strong effects on the accumulation of biomass in both shoot and root. With the increase of $\mathrm{P}$ concentration, there would be a sharp increase in partitioning of biomass to the shoot. The results of the present study were supported by the findings of Soundy et al. (2001) [10] who demonstrated that shoot FW and DW as well as leaf area of lettuce plants increased quadratically when $\mathrm{P}$ concentrations increased from
0 to $45 \mathrm{mg} / \mathrm{L}$. However, in eggplant (Solanum melongena), Villora et al. (2002) [30] reported that both the leaf blade and fruit FW as well as DW decreased significantly when $\mathrm{P}$ concentrations increased from $1 \mathrm{mM}$ to $4 \mathrm{mM}$. Our results also imply that the effect of hot A-RZT on shoot and root productivity were more severe compared to $\mathrm{P}$ deficiency.
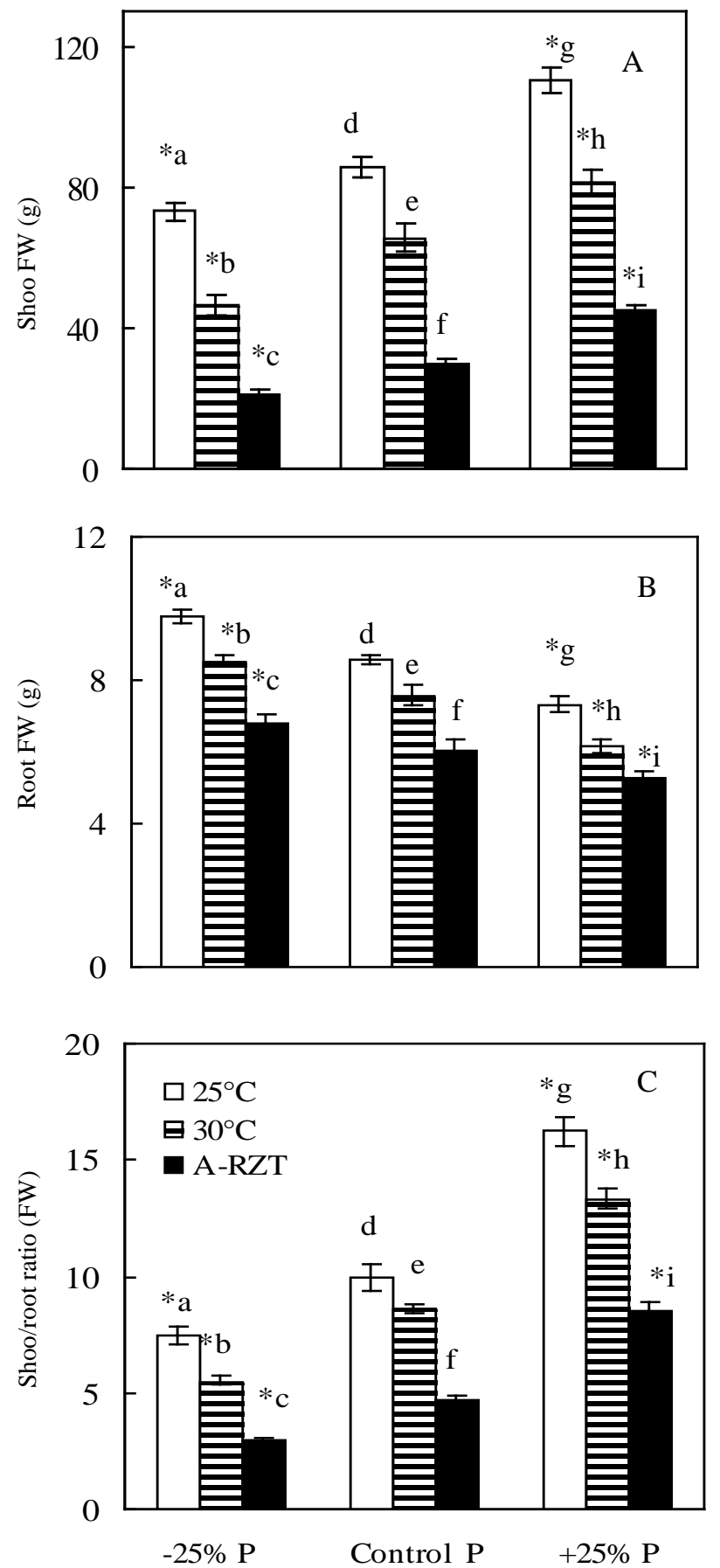

Fig. (1). Mean FW of shoots (A) and roots (B), and shoot/root ratios $(\mathbf{C})$ of $L$. sativa plants grown at three $\mathrm{P}$ (minus $\mathrm{P}=23.25 \mathrm{ppm}$, control $=31.00 \mathrm{ppm}$, and plus $\mathrm{P}=38.75 \mathrm{ppm}$ ) at three RZTs: $25^{\circ} \mathrm{C}$, $30^{\circ} \mathrm{C}$ and A-RZT, respectively. Vertical bars represent standard errors. * indicates significant difference by comparing to the control $\mathrm{P}(P<0.05)$ by t-test at the same RZT. Means within each $\mathrm{P}$ treatment followed by different letters are significantly different $(P<$ 0.05 ) based on Fisher's LSD test, $n=5$. 


\section{Root Morphology}

Root morphology analysis revealed that at each given RZT, total root length (Fig. 2A), total root surface area (Fig. 2B), total root volume (Fig. 2C) and total number of root tips (Fig. 2D) of lettuce plants grown with the minus $\mathrm{P}$ concentration were significantly greater than those of the control plants $(P<0.05)$. Meanwhile, all these root morphological parameters of lettuce plants grown with the plus $\mathrm{P}$ concentration were significantly lower than those of the control plants $(P<0.05)$. At each given $\mathrm{P}$ concentration, all parameters were much greater in $25^{\circ} \mathrm{C}$-RZT plants than in A-RZT plants. Plants grown with the minus $\mathrm{P}$ concentration at $25^{\circ} \mathrm{C}$ RZT had the largest total root length, largest total root surface area, largest total root volume and largest number of root tips among the different treatments. On the other hand, the results imply that RZT had greater effect on the development of root morphology than that of $\mathrm{P}$ concentration in the solution. At $25^{\circ} \mathrm{C}-\mathrm{RZT}$, for example, total root length of the minus P plants was 1.65-folds higher than that of the plus $P$ plants (Fig. 2A). However, with the minus $\mathrm{P}$ concentration, total root length of lettuce plants grown at $25^{\circ} \mathrm{C}-\mathrm{RZT}$ was 9.08-folds higher than that of A-RZT plants. For total root surface, total root volume and total root tips,similar results were obtained (Fig. 2B, 2C, 2D). With southern magnolia (Magnolia grandiflora Hort. 'St. Mary'), Martin and Ingram (1991) [31] found that total root length and root DW responded negatively to the increased RZT. Results of Tan et al. (2002) [4] showed that lettuce plants grown at $20^{\circ} \mathrm{C}-\mathrm{RZT}$ had longer total root length with more root tips and total root surface area. Also with lettuce, Qin et al. (2002) [22] obtained similar results. In their study, Tan et al. (2002) [4] found that hot A-RZT stunted the shoot growth as more photosynthates were partitioned to the roots for respiration and root cell thickening than root elongation. With Inex cronata "Rotundifolia", Foster et al. (1991) [32] reported that root respiration increased with increasing RZT.

A few more studies revealed that root growth was unaffected or even stimulated by moderate P deficiency $[6,14$, 33]. Studies carried out by Anghigoni and Barber (1980) [15] with maize (Zea mays) plants revealed that roots of Pdeficient plants were longer and slender compared to the plants grown at $\mathrm{P}$-sufficient medium. Anuradha and Narayanan (1991) [34] found that P-deficiency enhanced primary and secondary root elongation rate for horsegram (Macrtyloma unflorum) plants. These results could be caused by increased translocation of assimilated carbon from shoot to root [35]. In the present study, although the shoot productivity decreased for lettuce plants grown with the minus $\mathrm{P}$ concentrations, plants did not show any symptoms of $\mathrm{P}$ deficiency. On the other hand, the results in Fig. (2) demonstrated that the stimulating effect of lower $\mathrm{P}$ concentration in the solution on roots was dramatically diminished by hot ARZT. The integration of lower P concentration and hot RZT caused further decrease in shoot production.

\section{Maximum Photosynthetic Rate $\left(\mathbf{P}_{\max }\right)$}

As shown in Table 2, at each given RZT, $\mathrm{P}_{\max }$ of lettuce plants grown with the plus $\mathrm{P}$ concentration in the solution was significantly higher $(P<0.05)$ than those of the control $\mathrm{P}$ plants $(P<0.05)$. Meanwhile, $\mathrm{P}_{\max }$ of the plants grown with the minus $\mathrm{P}$ concentration was significantly lower than that of the control $\mathrm{P}$ plants $(P<0.05)$. It was also shown that lettuce plants grown at $25^{\circ} \mathrm{C}$-RZT had significantly higher $\mathrm{P}_{\max }$ compared to those of the plants grown at $30^{\circ} \mathrm{C}$-RZT
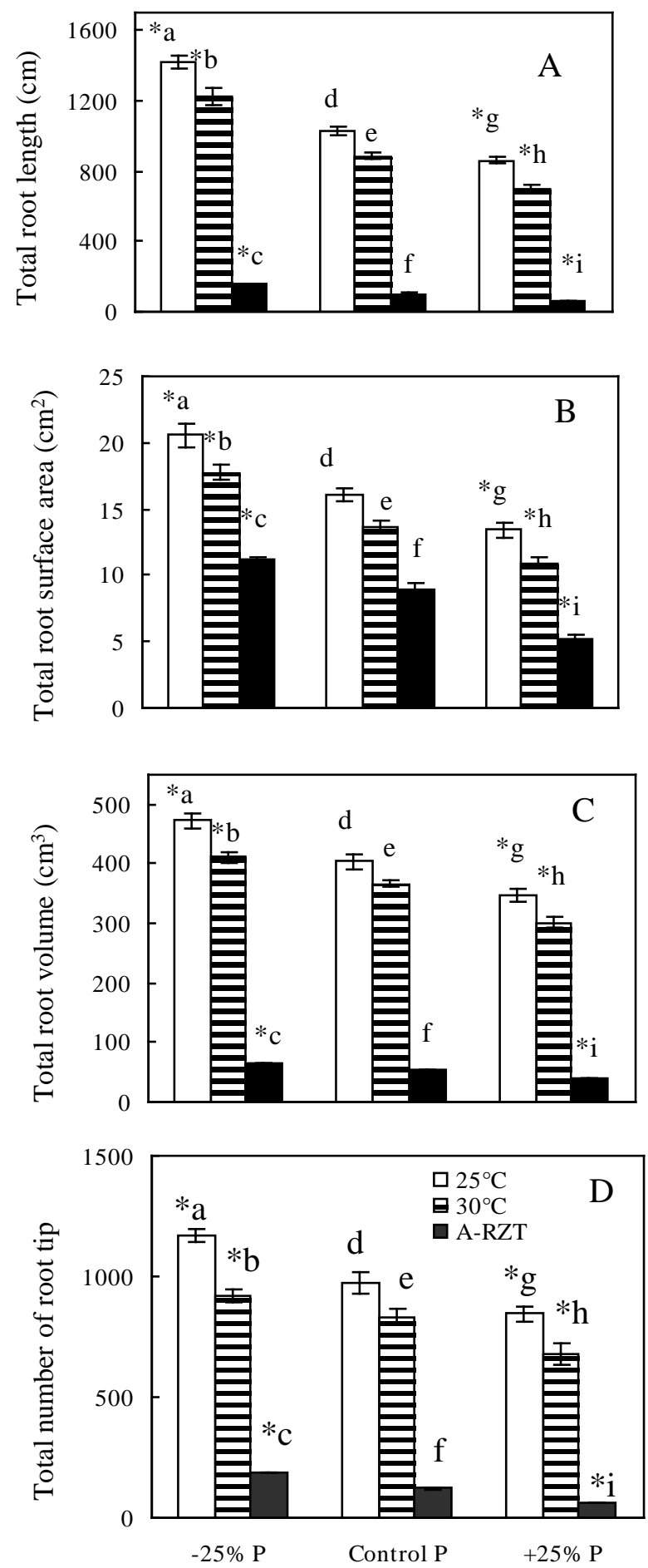

Fig. (2). Mean total root length (A), root surface area (B), root volume (C) and number of root tips (D) of L. sativa plants grown with three $\mathrm{P}$ concentrations (minus $\mathrm{P}=23.25 \mathrm{ppm}$, control $=31.00 \mathrm{ppm}$, and plus $\mathrm{P}=38.75 \mathrm{ppm}$ ) at three RZTs: $25^{\circ} \mathrm{C}, 30^{\circ} \mathrm{C}$ and A-RZT, respectively. Vertical bars represent standard errors (S.E.). * indicates significant difference by comparing to the control $\mathrm{P}(P<0.05)$ by t-test at the same RZT. Means within each P treatment followed by different letters are significantly different $(P<0.05)$ based on Fisher's LSD test. $\mathrm{n}=5$. 
Table 2. Mean $P_{\max }\left(\mu \mathrm{mol} \mathrm{O}_{2} \mathrm{~s}^{-2} \mathrm{~s}^{-1}\right)$ of $L$. sativa Plants Grown at Three $P$ Concentrations and RZTs for 35 Days

\begin{tabular}{|c|c|c|c|}
\hline RZT & $\mathbf{- 2 5 \%} \mathbf{P}$ & Control P & $\mathbf{+ 2 5 \% \mathbf { P }}$ \\
\hline \hline $25^{\circ} \mathrm{C}-R Z T$ & $11.77 \pm 0.77^{*_{\mathrm{a}}}$ & $14.65 \pm 1.21^{\mathrm{a}}$ & $18.18 \pm 0.29^{*_{\mathrm{a}}}$ \\
\hline $30^{\circ} \mathrm{C}-\mathrm{RZT}$ & $8.78 \pm 0.26^{*_{\mathrm{b}}}$ & $10.64 \pm 1.02^{\mathrm{b}}$ & $14.21 \pm 0.65^{{ }^{\mathrm{b}}}$ \\
\hline A-RZT & $7.06 \pm 1.02^{*_{\mathrm{c}}}$ & $8.83 \pm 0.90^{\mathrm{c}}$ & $11.74 \pm 0.87^{*_{\mathrm{c}}}$ \\
\hline
\end{tabular}

* Indicates significant difference by comparing to the control $\mathrm{P}(P<0.05)$ by t-test at the same RZT. Means within each P treatment followed by different letters are significantly different $(P<0.05)$ based on Fisher's LSD test, $\mathrm{n}=5$.

$(P<0.05)$ and A-RZT $(P<0.05)$. Results indicate that among all the treatments, lettuce plants grown with the plus $\mathrm{P}$ concentration at $25^{\circ} \mathrm{C}$-RZT had the highest $\mathrm{P}_{\max }$, suggesting that both higher $\mathrm{P}$ concentrations in the medium and cool RZT were needed by lettuce plants to maintain high photosynthetic rate when grown in the tropics. However, when grown at either A-RZT or $30^{\circ} \mathrm{C}-\mathrm{RZT}$, the effects of plus $\mathrm{P}$ on $\mathrm{P}_{\max }$ was masked by higher RZT. Among all the treatments, lettuce plants grown at the minus $\mathrm{P}$ concentration at A-RZT had the lowest $\mathrm{P}_{\max }$. In their study with maize (Z. mays) plants, Usuda and Shimogawara (1991) [36] indicated that for the plants grown with 0.001 (low P) and $0.5 \mathrm{mM}$ (control) $\mathrm{P}$ in the medium, low $\mathrm{P}$ treatment resulted in photosynthetic rate decreased by $68 \%$ compared to the control plants. In bean (P. vulgaris) plants, Mikulska et al. (1998) [5] found that 18-days' $P$ starvation resulted in photosynthetic rate declined to $50 \%$ of the control. $\mathrm{P}$ participates in plant photo- synthesis in the form of ATP, which supplies energy for the $\mathrm{CO}_{2}$ fixation [37].

Under P-deficient condition, ATP produced during photophosphorylation may be insufficient to support $\mathrm{CO}_{2}$ fixation by the Calvin cycle [38]. In okra (Abelmoschus esculentus) plant grown at P-deficiency, Sen and Mujkherji (2004) [39] found that both the ATP content and ATPase activity decreased significantly. In the present study, when lettuce plants were grown at $25^{\circ} \mathrm{C}-\mathrm{RZT}, \mathrm{P}_{\max }$ of the plus $\mathrm{P}$ at $25^{\circ} \mathrm{C}$ RZT plants was 2.6- and 1.55-folds higher than that of the plants gown with the minus $\mathrm{P}$ concentration at $25^{\circ} \mathrm{C}-\mathrm{RZT}$ and A-RZT, respectively. These results suggest that the promoting effect of higher $\mathrm{P}$ concentration on photosynthesis was debilitated by hot RZT. Studies with lettuce conducted by $\mathrm{He}$ and Lee (1998b) [2] reported that the values of $\mathrm{P}_{\max }$ were much lower in A-RZT plants than in $25^{\circ} \mathrm{C}-\mathrm{RZT}$ plants. Similar results were obtained by $\mathrm{He}$ and Lee (2001) [21] in another study conducted with Chinese broccoli (B. alboglabra).

Nevertheless, the results showed that the integration of $25^{\circ} \mathrm{C}-\mathrm{RZT}$ and higher $\mathrm{P}$ concentration in the solution additively enhanced photosynthetic rate compared to a single factor, that is, either cool-RZT or high P. Meanwhile, integration of low P and A-RZT additively depressed the photosynthetic rate than any of the single factor.

\section{P Uptake and Partitioning Between Shoots and Roots}

$\mathrm{P}$ concentrations of shoot and root as well as its partitioning between shoot and root are summarized in Table 3. At

Table 3. Mean P Concentrations (mg/g DW), Total P Content of Shoot and Root and P Shoot/Root Ratio of L. sativa Plants Grown at Different $P$ Concentrations in Nutrient Solution and Different RZTs for 35 Days

\begin{tabular}{|c|c|c|c|c|c|}
\hline \multicolumn{6}{|c|}{ Treatment } \\
\hline & & Tissue & $-25 \% \mathrm{P}$ & Control P & $+25 \% \mathrm{P}$ \\
\hline \multirow{6}{*}{$\begin{array}{l}\text { P concentration } \\
(\mathrm{mg} / \mathrm{g} \mathrm{DW})\end{array}$} & \multirow{2}{*}{$25^{\circ} \mathrm{C}-\mathrm{RZT}$} & Shoot & $5.81 \pm 0.46^{* a}$ & $6.62 \pm 0.58^{\mathrm{a}}$ & $7.86 \pm 0.48^{* a}$ \\
\hline & & Root & $5.07 \pm 0.36^{* \mathrm{~d}}$ & $5.67 \pm 0.40^{\mathrm{d}}$ & $7.07 \pm 0.53^{* \mathrm{~d}}$ \\
\hline & \multirow{2}{*}{$30^{\circ} \mathrm{C}-\mathrm{RZT}$} & Shoot & $4.8 \pm 0.37^{* b}$ & $5.76 \pm 0.46^{\mathrm{b}}$ & $7.01 \pm 0.49^{* b}$ \\
\hline & & Root & $4.73 \pm 0.22^{* e}$ & $5.95 \pm 0.28^{\mathrm{e}}$ & $6.83 \pm 0.41^{* \mathrm{e}}$ \\
\hline & \multirow{2}{*}{ A-RZT } & Shoot & $4.06 \pm 0.37^{* \mathrm{c}}$ & $4.79 \pm 0.36^{\mathrm{c}}$ & $5.84 \pm 0.49^{* \mathrm{c}}$ \\
\hline & & Root & $4.42 \pm 0.27^{* \mathrm{f}}$ & $5.31 \pm 0.23^{\mathrm{f}}$ & $5.95 \pm 0.35^{* \mathrm{f}}$ \\
\hline \multirow{9}{*}{$\begin{array}{l}\text { Total P content } \\
\qquad(\mathrm{mg})\end{array}$} & \multirow{2}{*}{$25^{\circ} \mathrm{C}-\mathrm{RZT}$} & Shoot & $20.06 \pm 2.06^{* a}$ & $29.17 \pm 2.61^{a}$ & $45.86 \pm 3.34^{* \mathrm{a}_{\mathrm{a}}}$ \\
\hline & & Root & $3.36 \pm 0.32^{* d}$ & $4.22 \pm 0.18^{\mathrm{d}}$ & $5.94 \pm 0.37^{* \mathrm{~d}}$ \\
\hline & \multirow{2}{*}{$30^{\circ} \mathrm{C}-\mathrm{RZT}$} & Shoot & $11.31 \pm 1.14^{* b}$ & $19.43 \pm 0.88^{b}$ & $31.04 \pm 1.47^{* b}$ \\
\hline & & Root & $2.74 \pm 0.23^{* \mathrm{e}}$ & $3.94 \pm 0.28^{b}$ & $5.12 \pm 0.35^{* \mathrm{e}}$ \\
\hline & \multirow{2}{*}{ A-RZT } & Shoot & $5.06 \pm 0.41^{*_{\mathrm{c}}}$ & $9.04 \pm 0.66^{c}$ & $16.56 \pm 1.07^{*_{c}}$ \\
\hline & & Root & $1.83 \pm 0.08^{* \mathrm{ff}}$ & $2.57 \pm 0.32^{\mathrm{f}}$ & $4.39 \pm 0.24^{* \mathrm{f}}$ \\
\hline & $25^{\circ} \mathrm{C}-\mathrm{RZT}$ & shoot/root ratio & $5.97 \pm 0.32^{\mathrm{a}}$ & $6.44 \pm 0.58^{\mathrm{a}}$ & $7.72 \pm 0.38^{* a}$ \\
\hline & $30^{\circ} \mathrm{C}-\mathrm{RZT}$ & shoot/root ratio & $4.13 \pm 0.29^{* b}$ & $4.69 \pm 0.4^{b}$ & $6.06 \pm 0.48^{* b}$ \\
\hline & A-RZT & shoot/root ratio & $2.76 \pm 0.23^{*_{\mathrm{c}}}$ & $3.52 \pm 0.17^{\mathrm{c}}$ & $4.92 \pm 0.28^{* \mathrm{c}}$ \\
\hline
\end{tabular}

* Indicates significant difference by comparing to the control $\mathrm{P}(P<0.05)$ by t-test at the same RZT. Means within each $\mathrm{P}$ treatment followed by different letters are significantly different $(P<0.05)$ based on Fisher's LSD test, $\mathrm{n}=5$. 
each given RZT, $\mathrm{P}$ concentration of shoot and root were significantly higher in the plus $\mathrm{P}$ plants than in the control plants $(P<0.05)$. Meanwhile, $\mathrm{P}$ concentrations of shoot and root were significantly lower in the minus $\mathrm{P}$ plants compared to those of the control plants $(P<0.05)$. On the other hand, $\mathrm{P}$ concentrations of shoot and root were significantly reduced when lettuce plants were grown at hot A-RZT. At each given $\mathrm{P}$ concentration in nutrient solution, $\mathrm{P}$ concentrations of shoot and root were significantly higher in $25^{\circ} \mathrm{C}$-RZT plants than in hot A-RZT plants $(P<0.05)$. Both shoot and root had the highest $\mathrm{P}$ concentration when lettuce plants were grown with the plus $\mathrm{P}$ concentration at $25^{\circ} \mathrm{C}$-RZT. With the minus $\mathrm{P}$ concentration and A-RZT, both shoot and root tissues had the lowest $\mathrm{P}$ concentrations. These findings suggest that there was a decrease in $\mathrm{P}$ concentrations of shoot and root when lettuce plants were grown with lower $\mathrm{P}$ concentration in the medium at hot A-RZT. Lettuce plants grown with plus $\mathrm{P}$ concentration at $25^{\circ} \mathrm{C}$-RZT had significantly higher shoot and root $\mathrm{P}$ concentrations compared to those plants grown with the plus $\mathrm{P}$ concentration at A-RZT $(P<0.05)$. These results suggest that $\mathrm{P}$ concentrations in both the shoots and root were affected by RZT and $\mathrm{P}$ concentration in nutrient solution. The effect of RZT on the accumulation of shoot and root $\mathrm{P}$ masked the effect of $\mathrm{P}$ concentrations in nutrient solution.

Our results were in agreement with those reported by Klock et al. (1997) [40]. P uptake and leaf P concentration decreased when tomato ( $L$. esculentum) seedlings were maintained at high $36^{\circ} \mathrm{C}$-RZT. In creeping bentgrass (A. palustris), Huang and $\mathrm{Xu}$ (2000) [41] reported that when roots were exposed to $36^{\circ} \mathrm{C}$-RZT, while shoots were kept at normal $20^{\circ} \mathrm{C}$, both shoot and root $\mathrm{P}$ concentrations decreased. The results of the present study also indicated that lettuce plants grown at $25^{\circ} \mathrm{C}$-RZT with the plus $\mathrm{P}$ concentration had the highest shoot and root $\mathrm{P}$ concentrations. The lowest shoot and root $\mathrm{P}$ concentrations were obtained from the plants grown at A-RZT with the minus $\mathrm{P}$ concentration in the nutrient solution. Lettuce plants grown with the plus P concentration had significantly higher shoot and root $\mathrm{P}$ concentrations compared to those of plants grown with the control and the minus $\mathrm{P}$ concentrations $(P<0.05)$.

In Table 3, results also showed that ratios of shoot/root $\mathrm{P}$ was significantly lower in control $\mathrm{P}$ plants than in the plus $\mathrm{P}$ plants $(P<0.05)$, but significantly higher than in the minus $\mathrm{P}$ plants $(P<0.05)$. As reported by Jeschke et al. (1997) [42], total amount of $\mathrm{H}_{2} \mathrm{PO}_{4}{ }^{-}$translocated to the shoots was reduced when castor bean (Ricinus communis) plants were grown at lower $\mathrm{P}$ medium. These could be related to the lower transpiration, as a higher proportion of water were retained in the roots and lower proportion was lost by transpiration in castor bean plants grown at lower $\mathrm{P}$ concentration [42]. In the present study, except for $\mathrm{P}$ availability, hot A-RZT inhibited not only the uptake but also the transport of $\mathrm{P}$ to the shoot, as $\mathrm{P}$ concentration of shoot was lower in ARZT plants than in $25^{\circ} \mathrm{C}$-RZT plants. Furthermore, at each given $\mathrm{P}$ concentration in nutrient solution, ratios of shoot/ root $\mathrm{P}$ were significantly higher in $25^{\circ} \mathrm{C}$-RZT plants than that in hot A-RZT plants $(P<0.05)$. These indicate that the proportion of absorbed $\mathrm{P}$ partitioned to shoot was significantly reduced when plants were grown at A-ZRT. The main factors that caused the reduction in the translation of $\mathrm{P}$ from roots to shoots could be related to the changes in root mor- phology under hot A-RZT. Tan et al. (2002) [4] and Qin et al. (2002) [22] reported that the development of root systems of lettuce plants were severely restricted when grown at hot A-RZT. Qin et al. (2003) [43] also reported that the uptake of water for lettuce plant grown at A-RZT was severely restricted. Graves et al. (1991) [44] and Dodd et al. (2000) [3] reported that root hydraulic conductivity decreased when lettuce plants were transferred from cool-RZT to hot A-RZT. In the present study, our results also indicate that root development was strongly depressed by hot A-RZT (Fig. 2). A1though the relative water content was not analyzed in this study, increased FW of shoot and root of $25^{\circ} \mathrm{C}-\mathrm{RZT}$ plants (Fig. 1) imply that lettuce plants grown at cool-RZT had higher water content compared to that of A-RZT plants.

\section{CONCLUSION}

Interaction between the plus $\mathrm{P}$ concentration in nutrient solution and $25^{\circ} \mathrm{C}$-RZT significantly enhance Pmax, thus the highest shoot and root productivity. However, plants grown with the minus $\mathrm{P}$ concentration at $25^{\circ} \mathrm{C}$-RZT developed the largest root system. Higher $\mathrm{P}$ concentration in growth medium resulted in higher $\mathrm{P}$ concentrations in shoots and roots with a greater portion partitioned to the shoots. However, uptake and transport of $\mathrm{P}$ to the shoot was depressed when lettuce plants were grown at hot A-RZT.

\section{ACKNOWLEDGMENT}

This research was supported by a research grant to RP 22/98 HJ from Academic Research Fund, Ministry of Education, Singapore.

\section{REFERENCES}

[1] He J, Lee SK. Growth and Photosynthetic characteristics of lettuce (Lactuca sativa L.) under fluctuating hot ambient temperatures with the manipulation of cool root-zone temperature. J Plant Physiol 1998a; 152: 87-391.

[2] He J, Lee SK. Effects of different root zone temperatures and growth irradiances on three lettuce cultivars (Lactuca sativa L.) grown under tropical aerial condition. I. Photosynthesis and productivity. J Hortic Sci Biotechnol 1998b; 73: 173-80.

[3] Dodd IC, He J, Turnbull CGN, Lee SK, Critchley C. The influence of supra-optimal root-zone temperatures on growth and stomatal conductance in Capsicum annuum L. J Exp Bot 2000; 51: 239-48.

[4] Tan LP, He J, Lee SK. Effects of Root-Zone Temperature on the Root Development and Nutrient Uptake of Lactuca sativa $\mathrm{L}$. cv 'Panama' Grown in an Aeroponic System in the Tropics. J Plant Nutr 2002; 25 (2): 297-314.

[5] Mikulska M, Bomsel JL, Rychter M. The influence of phosphate deficiency on photosynthesis, respiration and adenine nucleotide pool in bean leaves. Photosynthetica 1998; 35(1): 79-88.

[6] Xu G, Levkovitch I, Soriano S, Wallach R, Silber A. Integrated effect of irrigation frequency and phosphorus level on lettuce: $\mathrm{P}$ uptake, root growth and yield. Plant Soil 2004; 263: 297-300.

[7] Price NS, Rancadori RW, Hussey RS. Cotton root growth as influenced by phosphorus nutrition and vesicular- arbuscular mycorrhizas. New Phytol 1989; 111:61-6.

[8] Shah NH, Hafeez FY, Arshad M, Malik KA. Response of lentil to Rhizobium leguminosarum bv. viciae strains at different levels of nitrogen and phosphorus. Aust J Exp Agric 2000; 40(1): 93-8.

[9] Lynch J, Lauchli A, Epstein E. Vegetative growth of common bean in response to phosphorus nutrition. Crop Sci 1991; 31: 380-7.

[10] Soundy P, Cantliffe DJ, Hochmuth GJ, Stoffella PJ. Nutrient requirements for lettuce transplants using a floatation irrigation system II. Potassium. Hortic Sci 2001; 36(6): 1071-74.

[11] Stoltzfus RMB, Taber HG, Aiello AS. Effect of increasing rootzone temperature on growth and nutrient uptake by 'Gold Star' muskmelon plants. J Plant Nutr 1998; 21(2): 321-8. 
[12] Sattelmacher B, Marschner H, Kühne R. Effects of the temperature of the rooting zone on the growth and development of roots of potato (Solanum tuberosum). Ann Bot 1990; 65: 27-36.

[13] Hood MH, Mills HA. Root zone temperature affects nutrient uptake and growth of snapdragon. J Plant Nutr 1994; 17: 279-91.

[14] Forde B, Lorenzo H. The nutritional control of root development. Plant Soil 2001; 232: 51-68.

[15] Anghigoni I, Barber SA. Phosphorus influx and growth characteristics of corn as influenced by phosphorus supply. Agronomy J 1980; 72: 685-8

[16] Föhse D, Jungk A. Influence of phosphate and nitrate supply on root hair formation of rape, spinach and tomato plants. Plant Soil 1983; 74: 359-68.

[17] Lee SK. Aeroponic system as a possible alternative for crop production in Singapore. Common Agric Digest 1993; 3: 1-14.

[18] Douglas JS. Advanced guide to hydroponics. Pelham Books/ Stephen Greene Press 1989; p. 172.

[19] Ball MC, Chow WS, Anderson JM. Salinity-induced potassium deficiency causes loss of functional photosystem II in leaves of the gray mangrove forest. Aust J Plant Physiol 1987; 14: 351-61.

[20] Murphy J, Rileyt JP. A modified single solution method for determination of phosphorus in natural water. Anal Chim Acta 1962; 27, $31-6$

[21] He J, Lee SK. Relationship among photosynthesis, ribulose-1,5bisphosphate carboxylase (Rubisco) and water relations of the subtropical vegetable Chinese Broccoli grown in the tropics by manipulation of root-zone temperature. Environ Exp Bot 2001; 46: 119-28.

[22] Qin L, He J, Lee SK. Response of lettuce (Lactuca sativa L.) growth to reciprocal root-zone temperature (RZT) transfer at different growth stages. J Hortic Sci Biotechnol 2002; 77: 683-90.

[23] Bingham IJ, Cumbus IP. Influence of root temperature on the potassium requirement of young tomato plants. Plant Soil 1991; 133: 227-37.

[24] Lee SK, Cheong SC. Inducing head formation of iceberg lettuce (Latuca sativa L.) in the tropics. Trop Agric 1996; 73: 34-42.

[25] Salisbury FB, Ross CW. Plant Physiology. Wadsworth Publishing House: Belmont 1992; p. 540

[26] Sitton D, Itai C, Kende H. Decreased cytokinin production in the roots as a factor in shoot senescence. Planta 1967; 73: 296-300

[27] Crozier A, Reid DM. Do roots synthesis gibberellins? Can J Bot 1971; 21: 102-11.

[28] He J, Lee SK. Relationship among photosynthesis, ribulose-1,5bisphosphate carboxylase (Rubisco) and water relations of the subtropical vegetable Chinese Broccoli grown in the tropics by manipulation of root-zone temperature. Environ Exp Bot 2001; 46: $119-28$.
[29] Qin L, He J, Lee SK. Response of lettuce (Lactuca sativa L.) growth to reciprocal root-zone temperature (RZT) transfer at different growth stages. J Horticu Sci Biotechnol 2002; 77: 683-90.

[30] Víllora G, Moreno DA, Romero L. Phosphorus supply influences the molybdenum, nitrate and nitrate reductase activity in eggplant. J Hortic Sci Biotechnol 2002; 77(3): 305-9.

[31] Martin CA, Engram DJ. Root growth of southern magnolia following exposure to high root zone temperature. Hort Sci 1991; 26(4): 370-1.

[32] Foster WJ, Ingram DL, Terril A, Nell TA. Photosynthesis and root respiration in Inex cronata "Rotundifolia" at supraoptimal rootzone temperatures. Hortic Sci 1991; 26(5): 535-7.

[33] Rychter AM, Randall DD. The effect of phosphate deficiency on carbohydrates metabolism in bean roots. Physiol Plant 1994; 91: 383-8.

[34] Anuradha M, Narayanan AM. Promotion of root elongation by phosphorus deficiency. Plant Soil 1991; 136: 273-5.

[35] Ciereszko I, Gniazdowska A, Mikulska M, Rychter AM. Assimilate translocation in bean plants (phaseolus vulgaris L.) during phosphate deficiency. J Plant Physiol 1996; 149: 343-8.

[36] Usuda H, Shimogawara K. Phosphate deficiency in maize. I. Leaf phosphate status, growth, photosynthesis and carbon partitioning. Plant Cell Physiol 1991; 32: 497-504.

[37] Sivak MN, Walker DA. Photosynthesis in vivo can be limited by phosphate supply. New Phytol 1986; 102: 499-512.

[38] Krömer S. Respiration during photosynthesis. Annu Rev Plant Physiol Plant Mol Biol 1995; 46: 45-70.

[39] Sen S, Mukherji S. Alterations in activities of acid phosphatase, alkaline phosphatase, ATPase and ATP content in response to seasonally varying Pi status in okra (Abelmoschus esculentus). J Environ Biol 2004; 25(2): 181-5.

[40] Klock KA, Taber HG, Graves WR. Root respiration and phosphorus nutrition of tomato plant growth at $36^{\circ} \mathrm{C}$ root zone temperature. J Am Soc Hortic Sci 1997; 122(2): 175-8

[41] Huang BR, Xu QZ. Root growth and nutrient element status of creeping bentgrass cultivars differing in heat tolerance as influenced by supraoptimal shoot and root temperatures. J Plant Nutr 2000; 23: 979-90.

[42] Jeschke WD, Peuke A, Kirkby EA, Pate JS, Hartung W. Effects of $\mathrm{P}$ deficiency on assimilation and transport of nitrate and phosphate in intact plants of castor bean (Ricinus communis L.). J Exp Bot 1997; 48: 75-91

[43] Qin L. Ontogeny, root-zone temperature and growth irradiance effect on temperate and subtropical vegetable crops grown in the tropics. Ph.D. thesis 2003; p.149.

[44] Graves WR, Joly RJ, Dana N. Water use and growth of honey locust and tree-of-heaven at high root-zone temperature. Hortic Sci 1991; 26: 1309-12.

(C) Luo et al.; Licensee Bentham Open.

This is an open access article licensed under the terms of the Creative Commons Attribution Non-Commercial License (http://creativecommons.org/licenses/ by-nc/3.0/) which permits unrestricted, non-commercial use, distribution and reproduction in any medium, provided the work is properly cited. 